\title{
Real Estate Financing in Bangladesh: A Study on Sylhet Metropolitan City
}

\author{
Syed Mohammad Khaled Rahman ${ }^{1}$, Md. Tahidur Rahman ${ }^{2}$ \\ ${ }^{1}$ (Assistant Professor, Department of Business Administration, Shahjalal University of Science \& Technology, \\ Sylhet, Bangladesh) \\ ${ }^{2}$ (Associate Professor, Department of Business Administration, EXIM Bank Agricultural University \\ Bangladesh, Chapainawabganj, Bangladesh)
}

\begin{abstract}
Real estate business is mounting up as one of the most profitable sector in Sylhet- a region of high foreign remittance. Consequently, investors are paying their attention to invest in the sector for earning profit. Further prospect of real estate business in Sylhet is something moralizing for the investors. Only few apartment builder companies started their operations in the region. After 2000, private companies in this sector rapidly increased and the number of real estate and housing companies in Sylhet stood at 122 at the end of 2016. Among the companies 80 companies were found operation in full swing of which 50 companies were involved in real estate business and the remaining 30 companies were involved in real estate and housing business. The study has found shortage of debt financing as one of the major problems of real estate business in the region. The study also recommends financial institutions to reshuffle their policies for the smooth sanctioning of the loans to real estate companies and also to the customers of plot or flat. The findings of the study might be helpful to the authorities of the financial institutions, real estate and house building companies, policy makers of the government, and also to the existing and potential investors and customers.
\end{abstract}

Keywords: Real Estate Financing, Housing Business, Sylhet Metropolitan

\section{Introduction}

Bangladesh is a developing country with high density of population, low rate of per capita income, high poverty, and unemployment problem [1]. According to the Bangladesh Household Income and Expenditure Survey of 2010, the total number of household in Bangladesh is 33.03 million of which 24.17 million in rural areas and the remaining 8.86 million in urban areas [2]. The survey also reports that only $10.37 \%$ households in Bangladesh live in brick/cement structured houses (with roof) and a large majority of households live in wood and bamboo structured houses. With the increase of population, level of income, and standard of living, the demand of brick and cement structured house is increasing and the real estate and housing business is becoming one of the largest investment sectors in Bangladesh day by day [3]. Estimate suggests that there is a shortage of about 5 million houses in Bangladesh with around 0.5 million houses are being added annually in urban areas and 3.5 million are being added in rural areas [4].

Being a region of high foreign remittance, Sylhet contains great potentiality of real estate and housing business. As the city is becoming more densely inhabited, the problem of residence is also rising. With the development of private property ownership, real estate has become a major area of business. As urbanization increases, more and more people are becoming city dwellers and Sylhet is not an exception of the picture. The ever increasing urban population is creating an increasing demand for shelter. The right of shelter is a fundamental right, which is ensured in the constitution of Bangladesh and also in the UN declaration [5]. As it is very difficult from the part of government of Bangladesh alone to ensure housing for all, the need of private sector development has emerged.

Boom of this sector has a great impact on the economy of Bangladesh. It has created a large number of employment opportunities in construction as well as in marketing and selling of the construction materials and flats. According to Real Estate \& Housing Association of Bangladesh (REHAB), up to 2016 there were 1,151 private and public companies in this sector that has created employment opportunity for millions of people directly and indirectly[6]. During 1991-2008 the industry contributed to the national economy BDT 3700.87 billion with an average of BDT 217.70 billion per year and only in 2007-08 the sector contributed BDT 380.36 billion [7]. During 1991-2008 the average contribution of the sector to Gross Domestic Product (GDP) was 8.82\% As per REHAB report, the current contribution of real estate sector to GDP is approximately $12 \%$ to $15 \%$. Banking and other allied industries like cement, steels, woods, brick, and furniture are also largely dependent on this business. Further, government is generating a huge amount of exchequer in the form of tax and vat from this sector directly and indirectly. As the number of companies in this sector is increasing day by day, it is the demand of time to regulate the activities of real estate and housing business and to take proper initiative for the development of the sector. 
The core objective of the study is to explore the financing practices of real estate and house building companies in Bangladesh with special focus on Sylhet metropolitan city. The specific objectives of this study are:

a. to explore the growth and development of real estate and house building companies in Sylhet; and

b. to identify the problems and prospects of real estate and house building financing in Sylhet.

The remaining parts of the paper have been designed as follows: section two consists of methodology; section three explains the concepts of real estate financing; section four describes the historical development of real estate and housing business in Bangladesh and also in Sylhet Metropolitan City, section five consists of the data analysis and findings; and the last section six presents conclusion and recommendations.

\section{Methodology Of The Study}

Sources of Data: In conducting the study, both primary and secondary data have been used. A questionnaire survey was conducted to collect primary data from directors and executives of sample companies, bankers, and customers. Secondary sources cover: (i) published and unpublished documents of the companies; (ii) published and unpublished documents of the banks, REHAB, and chamber of commerce of Sylhet; (iii) Published and unpublished research works, books, journals, annual reports, and websites.

Selection of Sample: There are 122 Real estate and housing companies in Sylhet of which 80 companies were in operation during the study. Almost all the companies in the industry were private limited. In selecting samples, public limited companies and sole proprietorship firms have been excluded. Considering the time and cost, ten real estate companies have been taken as sample for conducting the study. Among financial institutions, nine private commercial banks and one non-bank financial institution that extend real estate loan have been taken as sample. The sample companies have been selected considering the convenience of data collection.

Selection of Respondents: Primary data consists of the opinions of directors and executives of sample companies, bankers and customers of different real estate companies. The numbers of respondents and the categories have been shown in Table-1:

Table 1: Number of respondents in different categories

\begin{tabular}{|c|l|c|}
\hline S1. No. & Category of respondents & Number of respondents \\
\hline 1 & Directors -one from each $(1 \times 10)$ & 10 \\
\hline 2 & Executives- one from each company (1×10) & 10 \\
\hline 3 & Bankers (Executives of 08 private commercial banks) & 08 \\
\hline 4 & Executive (02) from non-bank financial institutions & 02 \\
\hline 5 & Customers & 50 \\
\hline & Total & 80 \\
\hline
\end{tabular}

Collection and Analysis of Data: Primary data have been collected from the selected respondents through structured questionnaire surveyed by the researchers. Secondary data have been collected through personal contact and visit. The data so collected have been analyzed using different descriptive statistical techniques.

\section{Concept Of Real Estate And Real Estate Financing}

Real estate is a legal term that encompasses land along with anything permanently affixed to the land such as building [8]. However, in some situations the term real estate refers to the land and fixtures together as distinguished from real property referring to ownership rights of the land itself. Estate, in law, is the degree of interest or ownership that a person has in property. Real estate means land and everything made permanently a part thereof, and the nature and extent of one's interest therein. Real estate may be acquired, owned and transferred by individuals, business corporations, charitable, religious, educational, fraternal, and various other nonprofit corporations, fiduciaries such as trustees and executors, partnerships and generally by any legal entity as determined and defined by the laws. Real estate generally can be classified into five types such as- (i) Residential: all property used for housing, from small city lots to acreage, both single-family and multifamily, in urban, sub-urban, and rural areas; (ii) Commercial: business property, including offices, shopping centers, stores, theaters, hotels, and parking facilities; (ii) Industrial: warehouses, factories, and land in industrial districts; (iv) Agricultural: farms, timberland, pastureland, etc.; and (v) Special purpose: places of worship, schools, and government-held land.

Real estate finance can be defined as a branch of finance, which deals with investing money or wealth in real estate. It is related to the allocation, generation and use of monetary resources over time, which is invested in the real estate business. Like any other aspect of finance, real estate finance also has risks associated with it and the effective management of assets, which will maintain or increase in value over time, i.e. the investment yield of the project. Real estate investment essentially means investing in immovable properties such as land and everything attached to it such as buildings, also known as properties. The business can be viewed as a lucrative business opportunity as real estate can be pledged as collateral to secure a loan for a business venture or rental income can also be derived from a real estate property. Profits can be earned from real estate financing as a result of appreciation of real estate property prices, which is known as capital gains from real estate financing. 
Real estate financing can either be on residential or commercial properties, which have different tax implications. Real estate investment and financing decisions are inextricably linked and equity investors or borrowers treat real estate investment as much as a financing decision. The most recent development in the field of real estate finance has been the rise of real estate mortgaging business. Another feature associated with real estate financing is the Real Estate Investment Trust (REIT), which can be both privately and publicly held. A real estate investment trust is a corporation investing in real estate that reduces or eliminates corporate income taxes. In return, REIT's are required to distribute a majority of their taxable income to their shareholders. Only a handful of Asian economies such as Japan, Malaysia and Singapore have REITs in place [9].

Financing sources for commercial real estate include mortgage banking firms, savings and loan institutions, regional banks, insurance companies, and private investors. Commercial real estate financing can take on very different terms, and the way deals are structured is based on a number of factors, including: anticipated use of the property; anticipated returns from the property; geography; type of real estate; size of real estate; perceived risk to lender; market conditions etc. Each of these areas must be examined by the business owner prior to seeking commercial real estate financing. Business owners then need to examine the type of loans offered by lenders in accordance with their needs and anticipated growth. Unlike obtaining financing for residential real estate, where the transaction is based on the value of the home at the time of the sale, commercial real estate financing are based - in part, on the value of the business in the future.

Real estate is a lucrative business line, but it does involve considerable amounts of money. When a company wishes to raise real estate financing, it need to know at what stage of development the project in question is. Financers are aware of the fact that the transitional phase calls for the highest amount of required funding. The company will need to project estimated project costs for at least the first several months and maybe even longer and will need to draw up a new plan and cost estimate, since every project has its own specific funding requirements at various development stages. There is no general yardstick for start-up costs in a real estate project. Some projects call for only minimal funding, while others will entail huge costs in inventory or equipment. For a reasonable estimate of overall costs, the company must include all 'soft costs' during the inaugural stage. These will include the fee for obtaining permits, engineering costs and infrastructure and construction costs. Real estate financing can be either debt-based or equity-based.

In debt financing, real estate companies can borrow money from a creditor in exchange for future repayment along with interest. The lender has no ownership rights on the owner's business or interests, including the project he is financing. Debt financing is suitable when real estate firm do not wish to surrender any ownership interests in its business. In debt financing, the financing cost does not fluctuate and the loan is deductible. If the firm decide on real estate financing through equity, it can opts for either private equity through a real estate venture capital or private equity fund, or public equity. In public equity, it can opt for a listing on the local stock market, or a listing on a foreign market. It should remember that raising real estate financing from the public markets often turns out to be a costlier proposition, since it involves investment banking fees and other listing procedures. Finally, the way in which real estate firm generate real estate financing depends on its own strategic standpoint.

\section{Real Estate And Housing Business In Bangladesh And In Sylhet Metropolitan City}

Real Estate and Housing Business was first started in Dhaka, the capital city of Bangladesh, for providing residential facilities to the escalating population by Ispahani group in 1964. After the liberation Dhaka became one of the world's crowded cities. The population of the city was half a million in 1971 and it went to around 13 million by 1980 showing an increasing trend. In the early of 1980 Eastern Housing Ltd. came into in this sector to cope with the pressure of the growing population. Over the decades the government housing agencies, the Rajdhani Unnayan Kartipakkha (RAJUK) entered in the market for providing housing facilities to the city duelers. At present there are about 350 real estate companies working in the city. In order to strengthen the role of real estate sector, Real Estate \& Housing Association of Bangladesh (REHAB) was formed with only 11 members in 1991. REHAB is the only trade organization of real estate developers with current members of 1151 (REHAB, 2016). All major institutional developers are members of this organization. Though the real estate business was started in the Dhaka city, a number of real estate companies have been developed in the divisional cities of Bangladesh and also in many district cities.

In Sylhet, financing of house building was started with the establishment of a branch of House Building Finance Corporation (HBFC) in 1962. The branch was upgraded into a zonal office in 1995 and since then the activities have been widening. However, HBFC alone is still not capable of providing financial assistance to meet up the demand. To fill up the vacuum of government support in housing and to meet up the escalating demand, a number of private companies came into this sector. Moreover, expatriate people possesses sufficient fund and are interested to invest at home if congenial environment prevails here in this sector. Expatriates have interest to live with their family in Sylhet or they want to build their permanent residence at Sylhet after backing from abroad. Gradually, the demand of real estate and housing facility has been increasing in the city for the said reason. 
The private organizations in real estate and housing business at Sylhet started their journey in mid 1980s through the establishment of Qurayeshi Trading. They started Surma Abasik Prokalpo in 1998 and Diganta Abasik Prokalp in 1992. Man and Co. and Eastern Housing started their projects in Sylhet during 1998. Private companies in this sector has rapidly increased after 2000 and at present there are around 122 companies in Sylhet and at least 80 companies at present are in operation and out of which 50 real estate and 30 housing and real estate business and out of this 80, two are from out of Sylhet and three are the members of REHAB. For proper functioning of real estate business in Sylhet, a real estate sub-committee of Sylhet Chamber of Commerce has been formed with 24 members.

\section{Data Analysis And Findings}

For the purpose of this study, collected data about various aspects of real estate financing in Sylhet have been presented through the subsequent tables along with supporting discussion.

- Amount of Lending: The picture of lending to real estate sector in Sylhet by different financial institution has been shown in Table 2. The table shows that on average financial institutions disburse BDT 2.387 crore loans to real estate sector each year. It has been found in the study that the highest amount of real estate loan was disbursed by Agrani bank which was BDT 8 crore per year.

Table 2: Amount of Lending to Real Estate Sector Each Year

\begin{tabular}{|l|l|c|}
\hline Bank/Institution & Branch & Amount (BDT) \\
\hline Southeast bank & Chowhatta & 1 crore \\
\hline Delta Brac Housing & Kumarpara & 3.6 crore \\
\hline AB bank & Dorgahgate & 0.15 crore \\
\hline Trust Bank ltd. & Sylhet corporate & 1.5 crore \\
\hline IDLC & Sylhet & 3 crore \\
\hline IBBL & Laldighirpar & 0.60 crore \\
\hline Al-Arafah Islami bank & Sylhet & 0.52 crore \\
\hline Bank Asia Ltd. & Sylhet main br. & 0.50 crore \\
\hline IFIC & Sylhet main br. & 5 crore \\
\hline Agrani Bank & Bondorbazar & 8 crore \\
\hline Average & & 2.387 crore \\
\hline
\end{tabular}

Source: Field survey, 2016

- Composition of Real Estate Loan: The composition of long-term and short-term loan has been shown in Table 3. Most of the financial institutions provide long term loan to real estate sector rather than short term loan. IDLC provide only $10 \%$ short term loan, whereas the proportion of short term loan in real estate sector by Bank Asia and IFIC are $80 \%$ and $40 \%$ respectively.

Table 3: Composition of real estate loan provided by different financial institutions

\begin{tabular}{|l|l|c|c|}
\hline Bank/Institution & Branch & \multicolumn{2}{|c|}{ Composition of loan } \\
\hline & & Short term (in \%) & Long term (in\%) \\
\hline Southeast bank & Chowhatta & 0 & 100 \\
\hline Delta Brac Housing & Kumarpara & 0 & 100 \\
\hline AB bank & Dorgahgate & 0 & 100 \\
\hline Trust Bank ltd. & Sylhet corporate & 0 & 100 \\
\hline IDLC & Sylhet & 10 & 90 \\
\hline IBBL & Laldighirpar & 0 & 100 \\
\hline Al-Arafah Islami bank & Sylhet & 0 & 100 \\
\hline Bank Asia Ltd. & Sylhet main br. & 80 & 20 \\
\hline IFIC & Sylhet main br. & 40 & 60 \\
\hline Agrani Bank & Bondorbazar & 0 & 100 \\
\hline
\end{tabular}

Source: Field survey, 2016

- Interest on Real Estate Loan: It is evident from table 4 that average interest rate of short term and long term real estate loan was $15.5 \%$ and $15 \%$ respectively. On long term loan, the highest interest was charged by Southeast bank which was $16.5 \%$ where as the lowest interest was charged by $\mathrm{AB}$ bank which was $13 \%$ per year. On short term loan, Bank Asia charged $14.5 \%$ and other two institutions charged at $16 \%$ interest per year. 
Table 4: Annual interest rate on real estate loan

\begin{tabular}{|l|l|c|c|}
\hline Bank/Institution & Branch & Short term loan & Long term loan \\
\hline Southeast bank & Chowhatta & - & $16.5 \%$ \\
\hline Delta Brac Housing & Kumarpara & - & $14 \%$ \\
\hline AB bank & Dorgahgate & - & $13 \%$ \\
\hline Trust Bank ltd. & Sylhet corporate & $16 \%$ & $16 \%$ \\
\hline IDLC & Sylhet & - & $15 \%$ \\
\hline Islami bank & Laldighirpar & - & $15 \%$ \\
\hline Al-Arafah Islami bank & Sylhet & $14.5 \%$ & $14.5 \%$ \\
\hline Bank Asia Ltd. & Sylhet main br. & $16 \%$ & $16 \%$ \\
\hline IFIC & Sylhet main br. & - & $14 \%$ \\
\hline Agrani Bank & Bondorbazar & $15.5 \%$ & $15 \%$ \\
\hline Average & & & \\
\hline
\end{tabular}

Source: Field survey, 2016

- Duration of real estate loan: It is evident from table 5 that in 5 out of 10 institutions the duration of long term loan was above six years. Two bank's loan duration was below 6 years. Greater variability in maturity period of long term real estate loan was found in Islami Bank which was 2-10 years. Variability with respect to duration of long term real estate loan was also found in Delta Brac Housing and Agrani bank ltd. In short term loan lowest duration was evident in IDLC which was 1-3 month.

Table 5: Duration of real estate loan

\begin{tabular}{|l|l|c|c|}
\hline Bank/Institution & Branch & \multicolumn{2}{|c|}{ Duration of loan } \\
\hline & & Short term loan & Long term loan \\
\hline Southeast bank & Chowhatta & & $2-5$ years \\
\hline Delta Brac Housing & Kumarpara & & $5-10$ years \\
\hline AB bank & Dorgahgate & & $4-5$ years \\
\hline Trust Bank ltd. & Sylhet corporate & & $>6$ years \\
\hline IDLC & Sylhet & $1-3$ month & $>6$ years \\
\hline IBBL & Laldighirpar & & $2-10$ years \\
\hline Al-Arafah Islami bank & Sylhet & & $>6$ years \\
\hline Bank Asia Ltd. & Sylhet main br. & $9-12$ month & $>6$ years \\
\hline IFIC & Sylhet main br. & $3-6$ month & $>6$ years \\
\hline Agrani Bank & Bondorbazar & & $3-8$ years \\
\hline
\end{tabular}

Source: Field survey, 2016

- Proportion of Real Estate Loan: It is seen in table 6 that proportion of real estate loan out of total loan ranges from less than $5 \%$ to more than $25 \%$. Among the 10 commercial banks real estate loan of 4 banks on total loan was more than $25 \%$.

Table 6: Proportion of real estate loan in total loan

\begin{tabular}{|l|l|c|}
\hline Bank/Institution & Branch & Proportion of real estate loan (in \%) \\
\hline Southeast bank & Chowhatta & $20-25$ \\
\hline Delta Brac Housing & Kumarpara & $>25$ \\
\hline AB bank & Dorgahgate & $>25$ \\
\hline Trust Bank ltd. & Sylhet corporate & $20-25$ \\
\hline IDLC & Sylhet & $>25$ \\
\hline Islami bank & Laldighirpar & $<5$ \\
\hline Al-Arafah Islami bank & Sylhet & $15-20$ \\
\hline Bank Asia Ltd. & Sylhet main br. & $<5$ \\
\hline IFIC & Sylhet main br. & $20-25$ \\
\hline Agrani Bank & Bondorbazar & $>25$ \\
\hline
\end{tabular}

Source: Field survey, 2016

- Default Rate of Real Estate Loan: Default loan is a common agenda to all the lending institutions in Bangladesh. It is evident from table 7 that the default rate of real estate loan in most of the financial institution was less than $2 \%$. But $\mathrm{AB}$ bank showed the highest loan loss rate more that $10 \%$ followed by southeast bank $9 \%$. 
Table 7: Default rate of real estate loan

\begin{tabular}{|l|l|c|}
\hline Bank/Institution & Branch & Default loan (in \%) \\
\hline Southeast bank & Chowhatta & 9 \\
\hline Delta Brac Housing & Kumarpara & $<2$ \\
\hline AB bank & Dorgahgate & $>10$ \\
\hline Trust Bank ltd. & Sylhet corporate & $<2$ \\
\hline IDLC & Sylhet & $<2$ \\
\hline Islami bank & Laldighirpar & $<2$ \\
\hline Al-Arafah Islami bank & Sylhet & $<2$ \\
\hline Bank Asia Ltd. & Sylhet main br. & $<2$ \\
\hline IFIC & Sylhet main br. & $<2$ \\
\hline Agrani Bank & Bondorbazar & \\
\hline
\end{tabular}

Source: Field survey, 2016

- Types of Securities against Real Estate Loan: In practical, a variety of securities are required by the financial institutions for sanctioning real estate loan. Table 8 shows that mortgaged land and building was the most common type of security required by the financial institutions for sanctioning real estate loan in Sylhet.

Table 8: Types of Securities against Real Estate Loan

\begin{tabular}{|l|l|c|}
\hline Bank/Institution & Branch & Types of securities required \\
\hline Southeast Bank & Chowhatta & Registered mortgage deed \\
\hline Delta Brac Housing & Kumarpara & RSD, RM, TPA \\
\hline AB bank & Dorgahgate & Mortgaged property, primary securities \\
\hline Trust Bank & Sylhet corporate & Land, building and personal guarantee \\
\hline IDLC & Sylhet & Land, building, FDR, shop, registered original deed, \\
\hline Islami bank & Laldighirpar & Land mortgaged with construction \\
\hline Al-Arafah Islami Bank & Sylhet & Mortgaged property, land \\
\hline Bank Asia & Sylhet main br. & Mortgaged Land, building \\
\hline IFIC & Sylhet main br. & Mortgaged Land, building \\
\hline Agrani Bank & Bondorbazar & Land, building \\
\hline
\end{tabular}

Source: Field survey, 2016

- Rating of Interest Income from Real Estate Loan: In an attempt to measure the position of interest income from real estate loan as compared to other types of loan, a rating scale was used where rating point 1 meant the most favorable, whereas rating point 5 meant the most unfavorable position. From table 9 it is seen that real estate loan was not in a dominant position in case of generation of interest income as most of the institutions' ranking were 4 or 5 on a 5 -point rating scale.

Table 9: Rating of Interest Income from Real Estate Loan

\begin{tabular}{|l|l|c|}
\hline Bank/Institution & Branch & Rating \\
\hline Southeast bank & Chowhatta & 3 \\
\hline Delta Brac Housing & Kumarpara & 4 \\
\hline AB bank & Dorgahgate & 4 \\
\hline Trust Bank ltd. & Sylhet corporate & 2 \\
\hline IDLC & Sylhet & 3 \\
\hline Islami bank & Laldighirpar & 4 \\
\hline Al-Arafah Islami bank & Sylhet & 4 \\
\hline Bank Asia Ltd. & Sylhet main br. & 5 \\
\hline IFIC & Sylhet main br. & 4 \\
\hline Agrani Bank & Bondorbazar & 1 \\
\hline
\end{tabular}

Source: Field survey, 2016

- Criteria for Extending Real Estate Loan: Factors which are considered by banks for evaluating creditworthiness of real estate companies in extending real estate loan have been identified as: Past experience, Net worth, Social reputation, Past repayment performance, CRG, Income or earnings, Value of company's property, Successor, Security value and pattern, and Location. 
- Area and Number of Plots/Flats: From table 10 it is seen that the ownership pattern of most of the real estate company is private limited company. Plot trading company's area ranges from 16.5 acres to 300 acres.

Table 10: Total Area and Number of Plots/Flats

\begin{tabular}{|l|l|c|c|c|}
\hline Name of the Organization & \multicolumn{1}{|c|}{ Nature } & Product & Area Covered & Number of Plots/Flats \\
\hline The Man \& Company Ltd. & Company & Flat & 32,840 sq.ft & 160 \\
\hline Rupashi Bangla & Company & Plot & 75 acre & 100 \\
\hline Sylhet Dubai Land Development & Partnership & Plot & 36 acre & 20 \\
\hline Britania Samana & Partnership & Flat & 16.5 acre & 1200 \\
\hline Northeast home pvt. Ltd. & Company & Plot & 80 acre & 3000 \\
\hline Royal Homes Ltd. & Company & Plot & 300 acre & 40 \\
\hline BD Sthapona Ltd. & Company & Flat & 200 decimal & 24 \\
\hline Federal Associate Pvt. Ltd. & Company & Flat & 36 decimal & 60 \\
\hline Khadra International Ltd. & Company & Plot & 300 decimal & 2000 \\
\hline Ark Real Estate(Pvt.) Ltd. & Company & Plot & 330 acre & \\
\hline
\end{tabular}

Source: Field survey, 2016

- Initial Investment by Real Estate Companies: It is found from table 11 that average amount of initial investment by a real estate company was 16.98 crore taka and average total capital was 28.4 crore taka. Initial investment of three real estate companies was below BDT 1 crore.

Table 11: Initial Investment by Real Estate Companies

\begin{tabular}{|c|c|c|c|c|}
\hline \multirow[t]{2}{*}{ Name of the organization } & \multirow{2}{*}{$\begin{array}{c}\text { Initial investment } \\
\text { (in BDT Crore) }\end{array}$} & \multicolumn{2}{|c|}{ Amount of capital (in BDT Crore) } & \multirow{2}{*}{$\begin{array}{l}\text { Number of } \\
\text { Partners or } \\
\text { Shareholders }\end{array}$} \\
\hline & & Total & Initial & \\
\hline The Man \& Company Ltd. & $5-6$ & 24 & 4 & $>12$ \\
\hline Rupashi Bangla & $2-3$ & 16 & 3 & 9 \\
\hline Sylhet Dubai Land Development & $<1$ & 1.5 & 0.8 & 6 \\
\hline Britania Samana & $4-5$ & 4 & 2 & 4 \\
\hline Northeast home pvt. Ltd. & $4-5$ & 18 & 5 & $>12$ \\
\hline Royal Homes Ltd. & $5-6$ & 200 & 150 & 79 \\
\hline BD Sthapona Ltd. & $<1$ & 2 & 1.5 & 4 \\
\hline Federal Associate Pvt. Ltd. & $1-2$ & 5 & 2 & 49 \\
\hline Khadra International Ltd. & $<1$ & 1.5 & 0.5 & 17 \\
\hline Ark Real Estate(Pvt.) Ltd. & $7-8$ & 12 & 1 & $>12$ \\
\hline Average & & 28.4 & 16.98 & \\
\hline
\end{tabular}

Source: Field survey, 2016

- Sources of Initial Capital: From table 12 it is seen that the prime source of initial capital was equity or own source. On an average $87 \%$ of initial capital was raised from own source and the remaining $13 \%$ was raised from borrowing.

Table 12: Proportion of Sources of Capital by Real Estate Companies

\begin{tabular}{|l|c|c|c|}
\hline Name of the organization & Own (in \%) & Borrowed (in \%) & Total \\
\hline The Man \& Company Ltd. & 80 & 20 & 100 \\
\hline Rupashi Bangla & 100 & 0 & 100 \\
\hline Sylhet Dubai Land Development & 90 & 10 & 100 \\
\hline Britania Samana & 100 & 0 & 100 \\
\hline Northeast home pvt. Ltd. & 100 & 0 & 100 \\
\hline Royal Homes Ltd. & 50 & 50 & 100 \\
\hline BD Sthapona Ltd. & 100 & 0 & 100 \\
\hline Federal Associate Pvt. Ltd. & 100 & 0 & 100 \\
\hline Khadra International Ltd. & 50 & 50 & 100 \\
\hline Ark Real Estate(Pvt.) Ltd. & 100 & 0 & 100 \\
\hline Average & 87 & 13 & \\
\hline
\end{tabular}

Source: Field survey, 2016

DOI: $10.9790 / 5933-0803030109$ 
- Sources of Borrowings: Table 13 shows that real estate companies in Sylhet Regarding sources of borrowing both bank and non-bank sources are used. Three real estate companies use bank source and two companies use non-bank source for their borrowing.

Table 13: Proportion of Sources of Borrowings by Real Estate Companies

\begin{tabular}{|l|c|c|c|}
\hline Name of the organization & Bank borrowings (in \%) & From other sources (in \%) & Total \\
\hline The Man \& Company Ltd. & 0 & 100 & 100 \\
\hline Rupashi Bangla & N/A & N/A & \\
\hline Sylhet Dubai Land Development & 100 & 0 & 100 \\
\hline Britania Samana & N/A & N/A & \\
\hline Northeast home pvt. Ltd. & N/A & 50 & 100 \\
\hline Royal Homes Ltd. & 50 & N/A & \\
\hline BD Sthapona Ltd. & N/A & N/A & \\
\hline Federal Associate Pvt. Ltd. & N/A & 0 & 100 \\
\hline Khadra International Ltd. & 100 & N/A & \\
\hline Ark Real Estate(Pvt.) Ltd. & N/A & &
\end{tabular}

Source: Field survey, 2016

- Sources of Additional or Subsequent Capital: Table 14 shows that three real estate companies used solely own source for their additional capital. Four companies raised additional capital from both own source and profit. Two companies solely depend on profit for their additional capital.

Table 14: Sources of Additional or Subsequent Capital for Real Estate Companies

\begin{tabular}{|l|l|}
\hline Name of the Organization & Sources \\
\hline The Man \& Company Ltd. & Profit \\
\hline Rupashi Bangla & New equity \\
\hline Sylhet Dubai Land Development & New equity (50\%) and profit (50\%) \\
\hline Britania Samana & New equity and profit \\
\hline Northeast home pvt. Ltd. & New equity \\
\hline Royal Homes Ltd. & Profit \\
\hline BD Sthapona Ltd. & New equity \\
\hline Federal Associate Pvt. Ltd. & New equity (70\%) and profit(30\%) \\
\hline Khadra International Ltd. & Borrowing (50\%) and profit (50\%) \\
\hline Ark Real Estate(Pvt.) Ltd. & New equity and profit \\
\hline
\end{tabular}

Source: Field survey, 2016

- Installment Facility for Customers: Installment facility for the customers of flat or plot has been found a common feature in real estate business. From table 15 we see that all the customers got installment facility for the payment of purchased plot or flat.

Table 15: Customers' Response about Installment Facility

\begin{tabular}{|l|l|}
\hline Customers having installment facility & 50 \\
\hline Customers don't having installment facility & 0 \\
\hline Total number of customers & 50 \\
\hline
\end{tabular}

Source: Field survey, 2016

- Sources of Fund for Customer: From table 16 it is seen that a large majority of the customers (70\%) purchased plot or flat from their own source, whereas $26 \%$ purchased plot or flat from a combined source of own and borrowed money.

Table 16: Sources of fund for purchasing plot or flat

\begin{tabular}{|l|c|}
\hline Sources of fund & Number of customers \\
\hline Own & 35 \\
\hline Borrowing & 2 \\
\hline Both own and borrowed fund & 13 \\
\hline Total number of customers & 50 \\
\hline
\end{tabular}

Source: Field survey, 2016 
- Number and Nature of Installments: From table 17 it is evident that most of the customers (41 out of 50) provided monthly installments for their payment. The total number of installments was from 12 to 60 but the highest frequency ( 16 customers) was observed in 60 installments.

Table 17: Number of Installments and Installment Type

\begin{tabular}{|c|c|c|c|}
\hline Number of Installment & Number of Customers & Installment Type & Number of Customers \\
\hline 12 & 3 & Weekly & 0 \\
\hline 16 & 2 & Biweekly & 0 \\
\hline 20 & 5 & Monthly & 9 \\
\hline 24 & 2 & Quarterly & 0 \\
\hline 36 & 11 & Semi-annually & 0 \\
\hline 48 & 11 & Yearly & 0 \\
\hline 60 & 16 & Biyearly & Total \\
\hline Total & 50 & & 50 \\
\hline
\end{tabular}

Source: Field survey, 2016

\section{Conclusion And Recommendations}

The real estate business in Bangladesh started its tiny step with a very small number of companies. With the passes of the time, many companies joined that queue and, nowadays, the sector has become one of the largest contributors to the overall economy of the country. The housing and real estate business in Sylhet region has undergone many challenges. One of the major problems of real estate business is shortage of debt financing. Expansion of real estate companies is possible if they get adequate access to debt capital.

- Although some financial institutions including commercial banks provide real estate loan, the rules and regulations related to the loan are very tough. Therefore, loan sanctioning procedure should be made easier by financial institutions so that real estate companies can get more loans for their investment. Banks require collateral securities against any loan and also require lots of documents. Sometimes it becomes very tough to combine all these requirements by the real estate developers. As a result, the sanction of loan becomes delayed. Therefore, financial institutions should reshuffle their policies for the smooth sanctioning of the loans to real estate companies and also to the customers of plot or flat.

- It has been found that the proportion of debt capital in the capital structure of real estate companies is very low. It is therefore, recommended that real estate companies should raise more debt capital to exploit the benefits of financial leverage.

- Presently, the interest rate on real estate loan is very high, which is one of the hindrances to expansion of the sector. On the other hand, it has been found that most of the financial institutions have idle money. If banks lower interest rate on real estate loan, more loans can be extended in this sector and both the industry will ultimately be benefited.

- Special funds for housing development should be made available by the government in collaboration with the multilateral capital lenders. The government should also encourage the private sector and move toward publicprivate partnership in building affordable housing for lower income people.

\section{References}

[1] Bangladesh Economic Review (2015). Ministry of Finance. Government of the People Republic of Bangladesh.

[2] Report of the Household Income and Expenditure Survey (2010). Bangladesh Bureau of Statistics, Ministry of Planning, Government of the People Republic of Bangladesh.

[3] Kamal, M., \& Ahmed, S. (2016). Housing Finance Market in Bangladesh - A Review. IOSR Journal of Economics and Finance (IOSR-JEF), 7 (2), 31-40.

[4] Kamal, M., \& Hossain, M. S. (2016). Housing Finance Institutions in Bangladesh: A Study on Delta Brac Housing(DBH). International Journal of Economics, Commerce and Management , IV (4), 328-348.

[5] The Constitution of the People's Republic of Bangladesh, Article 15.

[6] Real Estate \& Housing Association of Bangladesh (REHAB), accessed on April 8, 2017 from http://www.rehab-bd.org/

[7] Bangladesh Economic Review (2008). Ministry of Finance. Government of the People Republic of Bangladesh.

[8] Holt, E. W. (2017). Accessed April 07 from http://www.ewholtlaw.com/real-estate

[9] Asia Asset Management. "The Rise of Asia's REITs." The Journal of Investments \& Pensions, January 29, 2013. Accessed April 07 from http://www.asiaasset.com/news/News_AsiaReit.aspx 